\title{
Meningkatkan ketahanan pangan bidang pertanian melalui budidaya tanaman sayur sayuran
}

Veny Triyana ${ }^{1}$, Marimbun ${ }^{2}$

${ }^{1}$ IAIN Langsa, Kota Langsa, Indonesia

\begin{tabular}{c|cc} 
First received: & Revised: & Final Accepted: \\
01 January 2021 & 02 February 2021 & 04 April 2021
\end{tabular}

\begin{abstract}
Abstrak
Tujuan Artikel ini adalah optimalisasi pemanfaatan pekarangan rumah meningkatkan ketahanan pangan bidang pertanian melalui budidaya tanaman sayur sayuran. Metode yang digunakan adalah melakukan penyuluhan: sosialisasi program, pelatihan, pengadaan benih tanaman dan sharing bersama. Hasil pengabdian ini adalah perubahan masyarakat untuk memanfaatkan lahan pekarangan rumah untuk budidaya tanaman sayur-sayuran. Meningkatnya ketahanan pangan pertanian melalui tanaman sayur_sayuran, Terciptanya Rumah Pangan Lestari Sayuran di lahan pekarangan rumah masyarakat di desa sidodadi kecamatan langsa lama.
\end{abstract}

Kata Kunci: Ketahanan pangan, budidaya, sayur- sayuran

\begin{abstract}
The purpose of this article is to optimize the use of house mats to increase food security in agriculture through the cultivation of vegetable crops. The method used is to conduct outreach: socialization programs, training, procurement of plant seeds and sharing together. The result of this service is a change in the community to use their home yards for cultivating vegetable crops. Increased agricultural food security through vegetable crops, the creation of a Sustainable Vegetable Food House on the yard of community houses in Sidodadi village, Langsa lama sub-district.
\end{abstract}

Keywords: Food security, cultivation, vegetables

\section{PENDAHULUAN}

Perguruan Tinggi berkewajiban dalam menyelenggarakan pendidikan, penelitian, dan pengabdian kepada masyarakat (Eniyati \& Noor, 2010). Oleh karena itu, Salah satu tugas perguruan tinggi adalah pengabdian kepada masyarakat. Pengabdian masyarakat merupakan kegiatan yang dapat mengasah ilmu dan keterampilan mahasiswa sehingga menjadi agen-agen perubahan dan pembangunan. Desa sidodadi merupakan salah satu nama desa dari 15 desa yang ada di kecamatan Langsa Lama, Kota Langsa, Provinsi Aceh. Penghasilan masyarakat pada umumnya adalah buruh kasar. Hampir semua rumah yang 
ada di Sidodadi memiliki lahan pekarangan yang sangat luas tetapi tidak dimanfaatkan oleh masyarakat.

Luas lahan setiap pekarangan rumah di Desa Sidodadi menjadi sangat berpotensi untuk menyediakan pangan seperti sayur- sayuran yang mempunyai keuntungan ekonomi setelah dikelola dengan baik. Hasil beberapa penelitian dan pengabdian dalam memanfaatkan lahan pekarangan rumah sudah terbukti sangat efektif dalam meningkatkan pendapatan masyarakat seperti hasil penelitian Yulida (2012), bahwa lahan pekarangan rumah dapat dimanfaatkan untuk meningkatkan perekonomian rumah tangga di kecamatan kerinci. Roidah (2014), bahwa memanfaatkan lahan yang ada di pekarangan rumah menggunakan sistem hidroponika dalam meningkatkan penghasilan masyarakat. Kegiatan pengabdian yang memfokuskan untuk peningkatan keterampilan ibu rumah tangga menyiapkan budidaya sayuran di dalam pot, serta menggunakan bahan-bahan yang ada di sekitar rumah untuk pembuatan pot dan pupuk organik cair (Dwiratna, Widyasanti, \& Rahmah, 2016). Hasil penelitian Khairunnisa (2018), bahwa pemanfaatan lahan pekarangan rumah berpotensi meningkatkan pendapatan masyarakat sehingga membantu perekonomian keluarga. Selanjutnya hasil penelitian Amruddin \& Iqbal (2018), pemanfaatan lahan pekarangan untuk memenuhi kebutuhan keluarga. Dewi \& Widiyawati (2019), memperkenalkan teknologi budidaya tanaman obat untuk memanfaatkan lahan pekarangan di Kelurahan Pabuwaran Purwokerto, Jawa Tengah. Diwanti (2018), memanfaatkan pekarangan rumah dengan teknik budidaya tanaman sayuran secara vertikultur. Hasil penelitian dan pengabdian terdahulu menjelaskan pentingnya memamfatkan lahan yang ada di sekitar rumah untuk meningkatkan perekonomian masyarakat.

Lahan yang ada dipekarangan masyarakat Sidodadi dapat dikembangkan untuk mempersiapkan kebutuhan sayur-sayuran bagi masyarakat. Namun, sebagian besar masyarakat belum memanfaatkan atau mengoptimalisasi lahan di pekarangan rumah untuk pengembangan pertanian sayur- sayuran. Hal ini bisa jadi disebabkan karena pengetahuan masyarakat dalam memanfaatkan pekarangan masih kurang khususnya penyediaan sayur- sayuran. Meningkatkan perekonomian atau pendapatan masyarakat di desa sidodadi dapat dilakukan optimalisasi pemanfaatan pekarangan rumah meningkatkan ketahanan pangan bidang pertanian melalui budidaya tanaman sayur sayuran dengan mengolah lahan pekarangan menjadi produktif. Optimalisasi memanfaatkan pekarangan rumah dilakukan untuk peningkatan fungsi lahan dan budidaya tanaman sayuran organik (Sasongko \& Salamah, 2019). Hasil pengabdian masyarakat Made dan Madinawati (2020), memberdayakan pekarangan dengan menanam sayur- sayuran dapat meningkatkan ketahanan pangan masyarakat. Dengan melakukan budidaya tanaman sayuran-sayuran di lahan pekarangan akan membantu masyarakat dalam menyediakan pangan yang sehat dan bergizi serta mendukung ketahanan pangan masyarakat.

Berdasarkan permasalahan tersebut, perlu dilakukan penyuluhan: sosialisasi program, pengadaan benih tanaman dan diskusi bersama, serta pelatihan sehingga masyarakat di desa sidodadi bisa lebih mandiri dan inovatif, kreatif dalam mengelola sumber daya alam yang ada dan berkecukupan pangan sehingga kesejahteraan masyarakatnya 


\section{METODE}

Metode yang digunakan dalam pengabdian kepada masyarakat ini adalah penyuluhan: sosialisasi program, pelatihan, pengadaan benih tanaman dan diskusi tentang pertanian. Penyuluhan dilakukan selama 45 hari di Desa Sidodadi Kecamatan Langsa Lama dimulai pada tanggal 01 Desember 2020 sampai 15 Januari 2021.

Sosialisasi: Lokasi kegiatan yang di lakukan di lorong 3 jalan kuburan di rumah kediaman ibu Ratih yang memiliki lahan pekarangan yang cukup subur untuk membuat Rumah Pangan Lestari Sayuran (RPLS). Tanah yang tandus dan basah memiliki kesuburan terhadap tanaman sayur- sayuran. Baik tanaman dari biji maupun bibit unggul yang sudah di tentukan. Bahan yang di tentukan untuk membuat olahan ketahanan pangan tanaman sayuran adalah tanah tandus yang bersifat basah dan subur. Tanah yang di jadikan untuk menanam sayur- sayuran dengan membuat Rumah Pangan Lestari Sayuran (RPLS). Terdapat 1 desa sasaran program di Kecamatan Langsa Lama, yaitu Desa Sidodadi, masing- masing desa dipilih 2 lorong target dan setiap lorong dibentuk 2 kelompok. Masing-masing kelompok terdiri dari 10 orang sehingga pada masing- masing desa terdapat 20 orang warga yang menjadi target pengabdian masyarakat.

Pelatihan: pembuatan pupuk organic dilakukan pada desa Sidodadi dari tanggal 14 Desember 2020 sampai 18 Desember 2020. Sebelum dilakukan pelatihan pembuatan pupuk organic terlebih dulu disiapkan tanah yang sudah dicangkul dan di campur dengan sampah organic. Pelaksana memberikan bantuan pupuk, plastik kepada masyarakat untuk membuat tanaman sayur-sayuran yang sifatnya permanen serta mengontrol pelaksanaan pembuatan tanaman tersebut. Pupuk organik yang ramah lingkungan dan jauh lebih murah dari pupuk kimia (Nugraha, 2016).
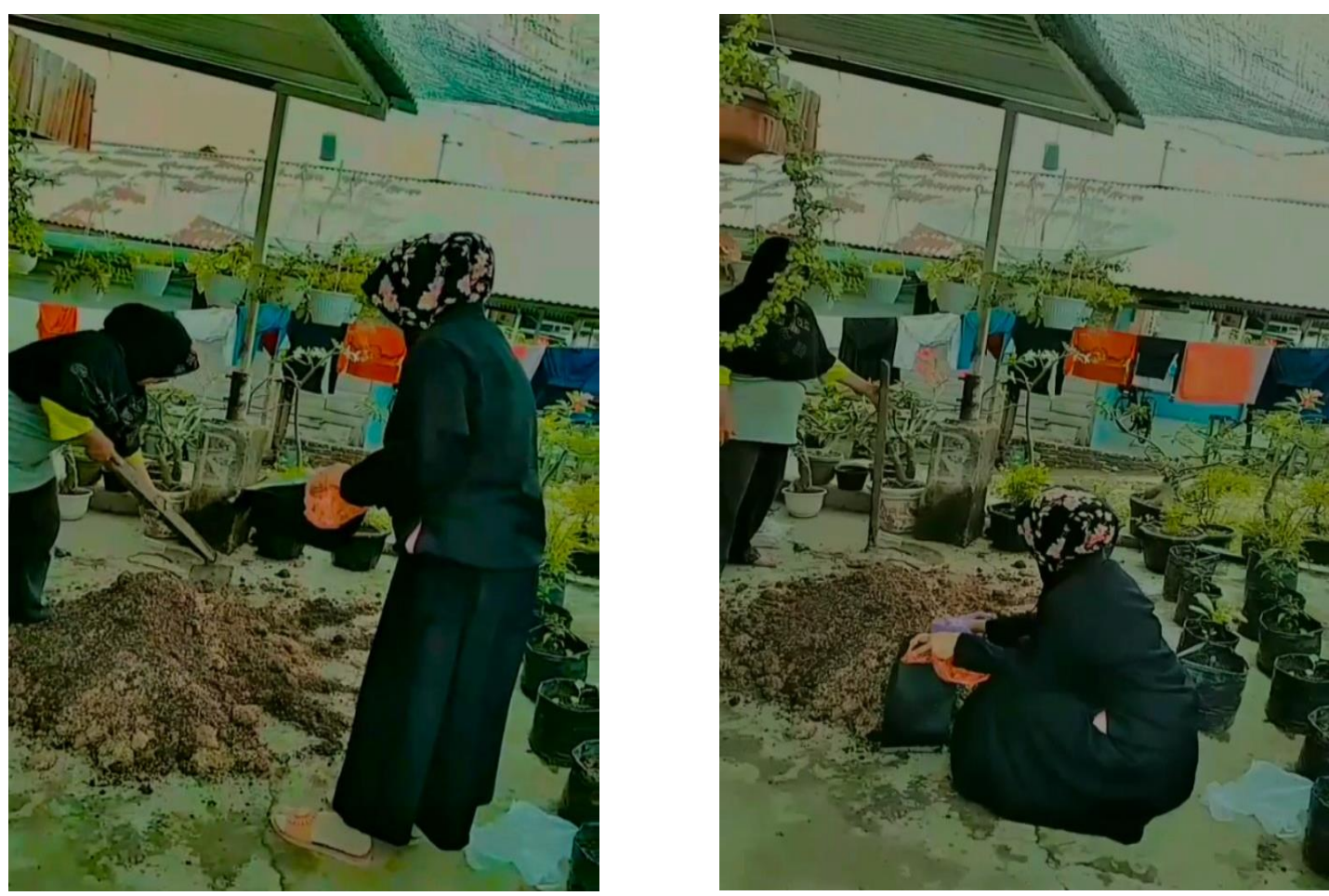

Gambar: Pengolahan Pupuk organik yang ramah lingkungan 
Pengadaan benih dan diskusi bersama: Pembuatan RPLS mulai dilakukan pada tanggal 21 Desember 2020 sampai dengan 25 Desember 2020 di desa Sidodadi Lorong 2. Tanaman yang di tanam di tiap- tiap RPLS adalah Tomat, Cabai, Sawi, Terong, Bayam (hijau), Kacang Panjang, Gambas, bunga kol, mentimun.(Setiawati, Murtiningsih, Sopha, \& Handayani, 2007; Suarsana, Kumbara, \& Satriawan, 2014)

\section{HASIL DAN PEMBAHASAN}

Ketahanan pangan bidang pertanian melalui budidaya tanaman sayur- sayuran. Masyarakat desa sidodadi menjadi antusias untuk berbondong dan mempunyai semangat yang tinggi menghasilkan bahan pangan bergizi yang di hasilkan dari tanaman di pekarangan rumah masing- masing. Masyarakat yang berada di desa sidodadi sangat antusias dalam mengikuti setiap kegiatan- kegiatan pemberdayaan yang dibuktikan dengan kehadiran/partisipasi dari warga desa dalam mengikuti setiap kegiatan. Masyarakat dari berbagai profesi punya semangat untuk meningkatkan ketahanan pangan program pertanian melalui tanaman sayur-sayuran. Kegiatan telah menghasilkan produk berupa pupuk organik cair dan padat yang di buat beserta masyarakat yang ikut berpartisipasi dalam pembuatan pupuk organik tersebut. Kegiatan pelatihan berjalan efektif untuk lebih mandiri dalam menyediakan pupuk pertanian organik ramah lingkungan (Nugraha, 2016).

Pemetikan hasil tanaman akan di lakukan ketika tanaman sudah mulai membesar dan bisa di jadikan masakan siap jadi untuk masyarakat desa sidodadi. Kebutuhan sehari- hari bagi para pekerja buruh sangat meyakinkan bahwa meningkatkan pertahanan bidang pertanian melalui budidaya tanaman sayuran akan semakin meningkat. Warga yang memiliki tanaman sayuran tersebut akan membantu meringankan hasil mata pencarian dan mengurangi uang pengeluaran untuk kebutuhan kehidupan sehari- hari. Masyarakat membangun Rumah Pangan Lestari Sayuran di masing- masing lahan pekarangan rumah. Tanaman yang sudah bisa di panen, menjadi olahan masakan bagi ibu rumah tangga yang berada di desa sidodadi kecamatan langsa lama. Membuat olahan masakan tradisi masyarakat aceh yaitu kuah pliek. Dalam pembuatan terdapat bahan sayur- sayuran yang di produksi dari hasil panen di RPLS tersebut.

\section{KESIMPULAN}

Optimalisasi pemanfaatan pekarangan rumah meningkatkan ketahanan pangan bidang pertanian melalui budidaya tanaman sayur sayuran menghasilkan pembuatan rumah pangan lestari sayuran serta pembuatan pupuk organik. Kegiatan pengabdian kepada masyarakat mendapat respon yang sangat baik dari masyarakat. 


\section{DAFTAR PUSTAKA}

Dewi, S. P., \& Widiyawati, I. (2019). Introduction of Medicinal Plant Cultivation as an Effort to Yard Utilization in Pabuwaran Village, Purwokerto, Central Java. Jurnal Panrita Abdi, 3(2), 107-111.

Dwiratna, S., Widyasanti, A., \& Rahmah, D. M. (2016). Pemanfaatan lahan pekarangan dengan menerapkan konsep kawasan rumah pangan lestari. Dharmakarya, 5(1), 19 22. Retrieved from http://jurnal.unpad.ac.id/dharmakarya/article/view/8873

Dyah Pikanthi Diwanti. (2018). Pemanfaatan pertanian rumah tangga (pekarangan rumah) dengan teknik budidaya tanaman sayuran secara vertikultur. MARTABE: Jurnal Pengabdian Masyarakat, 5(1), 101-107. Retrieved from https://core.ac.uk/download/pdf/235122238.pdf

Eniyati, S., \& Noor, C. (2010). Perancangan Sistem Pendukung Keputusan Penilaian Prestasi Dosen Berdasarkan Penelitian dan Pengabdian Masyarakat. Jurnal Teknologi Informasi DINAMIK, XV(2), 136-142.

Ida Syamsu Roidah. (2014). Pemanfaatan lahan dengan menggunakan sistem hidroponik. Jurnal Universitas Tulungagung BONOROWO, 1(2), 144-149. Retrieved from https://journal.unita.ac.id/index.php/bonorowo/article/view/14

Iqbal, A. A. M. (2018). Pemanfaatan lahan pekarangan sebagai upaya pemenuhan kebutuhan keluarga di desa kanjilo kecamatan barombong kabupaten gowa. Ziraa ah, 43(1), 70-76. Retrieved from https://ojs.uniskabjm.ac.id/index.php/ziraah/article/view/1073

Khairunnisa. (2018). Potensi Ekonomi Pemanfaatan Lahan Pekarangan di Kelurahan Sidodadi Kecamatan Wonomulyo Kabupaten Polewali Mandar (Universitas Islam Negeri Alauddin Makassar). Universitas Islam Negeri Alauddin Makassar. Retrieved from http://repositori.uin-alauddin.ac.id/13563/

Made, U., \& Madinawati. (2020). Pemberdayaan masyarakat pesisir melalui optimalisasi lahan pekarangan dengan budidaya sayuran organik untuk meningkatkan ketahanan pangan masyarakat. Abditani: Jurnal Pengabdian Masyarakat, 3(1), 14-19. Retrieved from http://abditani.jurnalpertanianunisapalu.com/index.php/abditani/article/view/38/29

Nugraha, A. W. (2016). Pemberdayaan kelompok tani dalam pembuatan pupuk organik cair ramah lingkungan dari bahan baku hayati. J-ADIMAS (Jurnal Pengabdian Kepada Masyarakat), 5(1), 10-15.

Sasongko, H., \& Salamah, Z. (2019). Optimalisasi lahan pekarangan rumah dengan budidaya tanaman sayuran organik di Dusun Krajan Desa Somongari Kec. Kaligesing Kab. Purworejo Hadi. Seminar Nasional Hasil Pengabdian Kepada Masyarakat Universitas Ahmad Dahlan, (14 September 2019), 1-8.

Setiawati, W., Murtiningsih, R., Sopha, G. A., \& Handayani, T. (2007). Petunjuk Teknis: Budidaya Tanaman Sayuran. Bandung: Balai Penelitian Tanaman Sayuran. 
Suarsana, N., Kumbara, N. A., \& Satriawan, K. (2014). Teknologi tepat guna panduan praktis praktis tanaman sayuran dan perkebunan. Denpasar: Udayana University Press.

Yulida, R. (2012). Kontribusi usahatani lahan pekarangan terhadap ekonomi rumah tangga petani di kecamatan kerinci kabupaten pelalawan. Indonesian Journal of Agricultural Economics (IJAE), 3(2), 135-154. Retrieved from https://ijae.ejournal.unri.ac.id/index.php/IJAE/article/view/1549 